\title{
COMBINING ABILITY STUDIES ON YIELD AND YIELD COMPONENTS IN RICE GENOTYPES (ORYZA SATIVA L.)
}

\author{
Maiwa'azi Abu BARDE ${ }^{1,2}$, Mohammed Sagir MOHAMMED ${ }^{2}$, Muhyideen OYEKUNLE ${ }^{2}$, \\ Inuwa Shehu USMAN ${ }^{2}$, Aondover SHAAHU $^{3 *}$ \\ ${ }^{1}$ National Agricultural Seeds Council, Abuja - Nigeria. \\ ${ }^{2}$ Plant Science Department, Ahmadu Bello University, Zaria - Nigeria. \\ ${ }^{3}$ National Cereals Research Institute, Badeggi, Niger State - Nigeria. \\ * Corresponding author. E-mail: iorpen001@gmail.com
}

\begin{abstract}
Nigeria has a wide range of arable rice growing environments including the inland valleys. Despite being the largest rice producer in West Africa, Nigeria is still a rice deficit nation. One of the major constraints to rice production in the inland valleys of Nigeria is iron $(\mathrm{Fe})$ toxicity. The understanding of the genetic basis of $\mathrm{Fe}$ tolerance mechanisms can provide useful information for the breeding of tolerant varieties. Based on the aforementioned, the research was conducted to study the general and specific combining ability for yield and its components and to estimate the gene action for seed yield and its components. Eight rice varieties were planted and crossed using incomplete diallel mating design to generate 28 hybrids which were evaluated along with the eight parents and two checks (Alhaji Baba and Ewodufagi) at Edozhigi during the 2017/2018 dry season. Data were collected on grain yield, days to $50 \%$ flowering, number of tillers, number of leaves, plant height, panicle length, number of seeds per panicle, panicle exertion, number of effective tillers, 1000 grain weight, first and second iron toxicity scores were subjected to diallel analysis of variance (ANOVA) for both parents and hybrids, using Statistical Analysis System (SAS) software package (2002). The results from the study are summarized as follows GCA and SCA mean squares were significant for most measured traits under iron toxicity hotspot, indicating importance of additive and non-additive gene action for controlling the traits. There was preponderance of additive gene effects over non-additive gene effects for all the traits measured indicating that additive gene action was more important in the inheritance of the traits under iron toxicity hotspot. FARO 52, SUAKOKO 8, CK-21 and CK-43 were good general combiners for grain yield under iron toxicity hot spot conditions.
\end{abstract}

Keywords: gene action, general combining ability, grain yield, iron toxicity, rice, specific combining ability.

\section{Introduction}

Rice (Oryza sativa L.) belongs to the family of grass (Poaceae) [CHANDRASEKARAN \& al. 2007] and it is one of the world's most important food crops with a total production of around 600 million tons, occupying $11 \%$ of the world's total arable land [GUIMARAES, 2009]. The crop supplies 2,808 calories/person/day, which represents $21 \%$ of the total calorie supply consumed by humans. Rice is an important annual crop in Nigeria and is one of the major staples.

Success of any plant breeding programme depends on the choice of appropriate genotypes as parents in the hybridization programme. The combining ability studies provide information, which helps in the selection of better parents for effective breeding programme. Combining ability analysis also provides information on additive and dominance variance. Its role is important to decide parents, crosses and appropriate breeding procedure to be followed to select desirable segregants [SALGOTRA \& al. 2009]. 
In Nigeria, lowland rice is cultivated on an estimated area of 3 million hectares out of which 1.8 million hectares are prone to iron toxicity [NCRI, 2012]. One of the areas where rice is commonly grown in Nigeria is Edozhigi village in Bida Local Government Area of Niger State. The people of this environment are predominantly lowland rice farmers. A survey conducted by the West African Rice Development Association (WARDA) in the area showed that average yield of lowland rice at Edozhigi seldom exceeds 1.5 tons ha $^{-1}$ [NARTEH \& SAHRAWAT, 1999]. Iron toxicity is a nutritional disorder associated with high level of ferrous iron concentration in the soil and is found mainly in waterlogged lowlands [CHERIF \& al. 2009]. The response of rice to iron toxicity varies among different rice varieties. Some varieties have the mechanism to retain high iron levels in their roots or as oxides in the rhizosphere while other varieties are susceptible to iron toxicity, expressed in poor adaptability to iron toxicity stressed environment [MANDAL \& al. 2004]. FUKUDA $\&$ al. (2012), reported that the surest way to counter iron toxicity is by using tolerant rice varieties. Genetic improvement of iron-toxicity tolerance implies the need of varietal screening to make good use of the existing diversity for iron toxicity tolerance. Since rice is a staple food in Nigeria, low production due to iron toxicity threatens the country's food security.

Several researches have been carried out on iron toxicity effects on rice production around the world. But in Nigeria, works on iron toxicity in rice have been based on mere selection. Therefore, adequate information has not been clearly understood about the constraint. Understanding of the genetic basis of iron tolerance mechanisms can provide useful information that will guide in designing strategic programme for the breeding of iron toxicity tolerant rice varieties. Consequently, knowing genetic bases of the materials formed the basis of this research. The objectives of the present study were to determine; Genetic variability of some agronomic traits for iron toxicity in rice: to study the general and specific combining ability for yield and its components and to estimate the gene action for seed yield and its components.

\section{Materials and methods}

\section{Experimental site and climate}

The research was conducted at the National Cereals Research Institute (NCRI) research field Edozhigi, Bida in Niger State from November 2017 to February 2018. NCRI research field Edozhigi is known to be an iron toxicity hot spot located in the Southern Guinea Savannah agro ecological region of Nigeria which has geographical bearing of latitude $09^{\circ} 45^{\prime}$ $\mathrm{N}$, longitude $06^{\circ} 07^{\prime} \mathrm{E}$ and altitude $50.57 \mathrm{~m}$ above the sea level (Table 1). It has bimodal rainfall pattern with an annual rainfall of about $900-1050 \mathrm{~mm}$ distributed between May and October. The average daily temperature is $35{ }^{\circ} \mathrm{C}$ with an annual mean of $27.4{ }^{\circ} \mathrm{C}$ and the mean relative humidity of about $52-73 \%$ [OGAH, 2013].

Table 1. Soil analysis of the study area: Edozhigi, Bida, Niger State, 2018

\begin{tabular}{lcc}
\hline Parameters & $\mathbf{0 - 1 5} \mathbf{~ c m}$ value & $\mathbf{1 5 - 3 0 ~ c m ~ v a l u e ~}$ \\
\hline Sand (\%) & 84.96 & 83.24 \\
Silt (\%) & 10.56 & 8.28 \\
Clay (\%) & 4.48 & 8.48 \\
USDA Textural Class & Sandy loam & Sandy loam \\
pH $\left(\mathrm{H}_{2} \mathrm{O}\right)$ & 4.64 & 4.65
\end{tabular}


Maiwa'azi Abu BARDE \& al.

\begin{tabular}{lcc} 
Organic Carbon $(\%)$ & 0.59 & 0.68 \\
Organic Matter $(\%)$ & 1.02 & 1.18 \\
Total Nitrogen $(\%)$ & 0.15 & 0.10 \\
Available Phosphorus $(\mathrm{mg} / \mathrm{kg})$ & 25.00 & 26.88 \\
Exchangeable Bases $(\mathbf{C m o l} / \mathrm{kg})$ & & \\
Calcium $\left(\mathrm{Ca}^{2+}\right)$ & 2.48 & 2.88 \\
Magnesium $\left(\mathrm{Mg}^{2+}\right)$ & 4.63 & 5.90 \\
Sodium $\left(\mathrm{Na}^{+}\right)$ & 0.17 & 0.13 \\
Potassium $\left(\mathrm{K}^{+}\right)$ & 0.15 & 0.20 \\
Exchangeable Acidity $(\mathrm{Cmol} / \mathrm{kg})$ & 0.05 & 0.08 \\
Cation Exchange Capacity $(\mathrm{Cmol} / \mathrm{kg})$ & 7.48 & 9.19 \\
Fe $\left(\mathrm{mgkg}^{-1}\right)$ & 546 & 537 \\
\hline
\end{tabular}

\section{Experimental materials}

The experimental materials comprised of eight genotypes of rice five obtained from the National Cereals Research Institute (NCRI) Badeggi, Niger State and three from West African Rice Centre, Ibadan. The description of the rice genotypes is presented in Table 2.

\section{Development of $F_{1}$ population}

The eight rice genotypes were mated using half diallel mating design method IV model I to generate $28 \mathrm{~F}_{1}$ (Table 3 ). Seeds were planted in 128 buckets in four successions at an interval of one week (32 buckets in each succession) to synchronize flowering. Emasculation was carried out between 07.00 am and 09.00 am which involved direct removal of anthers before anthesis. In rice, anthers are enclosed in lemma and palea. Scissors was used to cut the un-matured caryopsis to expose the anthers and carefully removed with forceps without causing damage to the style and stigma. For the hybridization, flowers containing matured pollen grains from the male plants were shed on the emasculated panicles between 10am and 12noon. Pollinated flowers were covered with envelops sizeable enough to avoid contaminations and damages [MOHANAN, 2010].

Field evaluation of the $F_{1}$ genotypes and their parents

The eight parents, $28 \mathrm{~F}_{1}$ hybrids and two checks making a total of 38 entries were evaluated at an iron toxicity spot in-situ at Edozhigi, Niger State. Plots were laid in a randomized complete block design with three replications. The genotypes were randomly planted with five stands per plot at $20 \mathrm{~cm} \times 20 \mathrm{~cm}$ inter and intra row spacing respectively. All cultural practices for rice production were carried out in accordance with the recommendations of the NCRI, Badeggi.

Table 2. Description of the genetic materials used for the study

\begin{tabular}{cccccc}
\hline Genotype/variety & Source & $\begin{array}{c}\text { Potential yield } \\
(\mathbf{k g} / \mathbf{h a})\end{array}$ & $\begin{array}{c}\text { Plant height } \\
(\mathbf{c m})\end{array}$ & $\begin{array}{c}\text { Maturity } \\
\text { days }\end{array}$ & $\begin{array}{c}\text { Reaction to } \\
\text { Iron Toxicity }\end{array}$ \\
\hline FARO 44 $\left(\mathrm{P}_{1}\right)$ & NCRI & 6442 & 115 & $95-105$ & $\mathrm{~S}$ \\
FARO52 $\left(\mathrm{P}_{2}\right)$ & NCRI & 6710 & 129 & $125-135$ & $\mathrm{~T}$ \\
FARO 60 $\left(\mathrm{P}_{3}\right)$ & NCRI & 6754 & 120 & $100-115$ & $\mathrm{~S}$ \\
FARO 57 $\left(\mathrm{P}_{4}\right)$ & NCRI & 7954 & 124 & $120-135$ & $\mathrm{~T}$ \\
FARO61 $\left(\mathrm{P}_{5}\right)$ & NCRI & 6312 & 115 & $100-110$ & $\mathrm{~S}$ \\
SUAKOKO 8 $(\mathrm{P} 6)$ & WARDA & 5500 & 141 & $115-120$ & $\mathrm{~T}$ \\
CK- 43 $\left(\mathrm{P}_{8}\right)$ & WARDA & 5000 & $75-80$ & $80-90$ & $\mathrm{~T}$ \\
\hline
\end{tabular}

Source: NCRI/WARDA 2017, S: Susceptible, T: Tolerant. 


\begin{tabular}{lcccccccc}
\hline \multicolumn{6}{c}{ Table 3. Diallel method IV Model 1 adopted to develop the plant population used in the study } \\
\hline \multicolumn{1}{c}{$\mathbf{P}_{\mathbf{1}}$} & $\mathbf{P}_{\mathbf{2}}$ & $\mathbf{P}_{\mathbf{3}}$ & $\mathbf{P}_{\mathbf{4}}$ & $\mathbf{P}_{5}$ & $\mathbf{P}_{6}$ & $\mathbf{P}_{7}$ & $\mathbf{P}_{8}$ \\
\hline $\mathbf{P}_{1}$ & $\mathrm{P}_{1} \mathrm{P}_{2}$ & $\mathrm{P}_{1} \mathrm{P}_{3}$ & $\mathrm{P}_{1} \mathrm{P}_{4}$ & $\mathrm{P}_{1} \mathrm{P}_{5}$ & $\mathrm{P}_{1} \mathrm{P}_{6}$ & $\mathrm{P}_{1} \mathrm{P}_{7}$ & $\mathrm{P}_{1} \mathrm{P}_{8}$ \\
$\mathbf{P}_{2}$ & & $\mathrm{P}_{2} \mathrm{P}_{3}$ & $\mathrm{P}_{2} \mathrm{P}_{4}$ & $\mathrm{P}_{2} \mathrm{P}_{5}$ & $\mathrm{P}_{2} \mathrm{P}_{6}$ & $\mathrm{P}_{2} \mathrm{P}_{7}$ & $\mathrm{P}_{2} \mathrm{P}_{8}$ \\
$\mathbf{P}_{3}$ & & & $\mathrm{P}_{3} \mathrm{P}_{4}$ & $\mathrm{P}_{3} \mathrm{P}_{5}$ & $\mathrm{P}_{3} \mathrm{P}_{6}$ & $\mathrm{P}_{3} \mathrm{P}_{7}$ & $\mathrm{P}_{3} \mathrm{P}_{8}$ \\
$\mathbf{P}_{4}$ & & & & $\mathrm{P}_{4} \mathrm{P}_{5}$ & $\mathrm{P}_{4} \mathrm{P}_{6}$ & $\mathrm{P}_{4} \mathrm{P}_{7}$ & $\mathrm{P}_{4} \mathrm{P}_{8}$ \\
$\mathbf{P}_{5}$ & & & & & $\mathrm{P}_{5} \mathrm{P}_{6}$ & $\mathrm{P}_{5} \mathrm{P}_{7}$ & $\mathrm{P}_{5} \mathrm{P}_{8}$ \\
$\mathbf{P}_{6}$ & & & & & & $\mathrm{P}_{6} \mathrm{P}_{7}$ & $\mathrm{P}_{6} \mathrm{P}_{8}$ \\
$\mathbf{P}_{7}$ & & & & & & & $\mathrm{P}_{7} \mathrm{P}_{8}$ \\
$\mathbf{P}_{8}$ & & & & & & & & \\
\hline
\end{tabular}

Key: P1: FARO 44, P2: FARO 52, P3: FARO 60, P4: FARO 61, P5: SUAKOKO 8, P6:FARO57 P7: CK-21, P8: CK-43.

Data were collected on the followings traits: Plant height at maturity $(\mathrm{cm})$, Number of tillers, Number of leaves, Days to 50\% flowering, Panicle length $(\mathrm{cm})$, Number of seeds per panicle, Iron toxicity score: This was recorded on the scale 1 to 9 , where $1.0=$ highly resistance, $3.0=$ resistance, $5.0=$ moderately susceptible, $7.0=$ susceptible and $9.0=$ highly susceptible IRRI $I_{\text {SES, }}$ (2001), Grain Yield after harvest (g), Number of effective tillers, One thousand (1000) grain weight (g) and Panicle Exertion.

\section{Statistical Analysis}

The data collected were subjected to analysis of variance (ANOVA). Using general linear model procedure of Statistical Analysis System (SAS) package (2002). Significant difference between treatments means were compared using least significant difference (LSD) using linear model as shown below:

$$
Y_{i j k}=\mu+\alpha_{i}+r_{j}+\ell_{i j k}
$$

Where: $Y_{i j k}$ is the observation in treatment $\mathrm{i}$ and block $\mathrm{j}$ and $\mathrm{k}$,

$\mu$ is the overall mean, $\alpha_{i}$ is the effect of treatment, $\ell_{i j k}$ is the random error.

\section{Results}

\section{Combining ability and gene action}

The analysis of variance for general combining ability (GCA) and specific combining ability $(\mathrm{SCA})$ of $\mathrm{F}_{1}$ genotypes showed highly significant $(\mathrm{P}<0.01)$ differences for all traits measured (Table 4). The mean squares due to GCA and SCA were highly significant $(\mathrm{P}<0.01)$ for most of the traits except for the number of seeds per panicle and first iron toxicity score which were not significantly different.

Estimate of general combining ability effect for grain yield and other agronomic traits of rice under iron toxicity hotspot at edozhigi

A highly significant $(\mathrm{P}<0.01)$ positive GCA effects for grain yield were observed for FARO 52 (19.93). Highly significant $(\mathrm{p}<0.01)$ positive GCA effects for grain yield were observed for suakoko 8(8.67) and highly significant $(\mathrm{P}<0.01)$ negative GCA effects of first and second iron toxicity scores of $(-0.73)$ and $(-1.19)$, respectively, (Table 5). Highly 
Maiwa'azi Abu BARDE \& al.

significant $(\mathrm{p}<0.01)$ positive GCA effects for days to $50 \%$ flowering were observed for FARO 57 (3.42) and Suakoko 8 (3.42) and highly significant negative GCA effects were observed for FARO 60 (-6.70) and CK-43 (-5.5).

Table 4. Analysis of variance for general combining ability (GCA) and specific combining ability (SCA) evaluated at iron toxicity condition at Edozhigi, in 2018

\begin{tabular}{|c|c|c|c|c|c|}
\hline Source of variation & Replication & Genotype & GCA & SCA & Error \\
\hline Df & 2 & 37 & 7 & 27 & 70 \\
\hline Grain yield (kg/ha) & 35.11 & $3614 * *$ & $13046.07 * *$ & $1112.49 * *$ & 102.9422 \\
\hline Days to flowering & 3.06 & $364 * *$ & $515.99 * *$ & $328.85 * *$ & 54.8194 \\
\hline Number of tillers & 36.05 & $126.41 * *$ & $326.50 * *$ & $84.21 * *$ & 22.6187 \\
\hline Number of leaves & 0.86 & $2.12 * *$ & $7.10 * *$ & $0.94 * *$ & 0.42067 \\
\hline plant height $(\mathrm{cm})$ & 98.93 & $1707.60 * *$ & $6077.39 * *$ & $574.29 * *$ & 140.711 \\
\hline panicle length $(\mathrm{cm})$ & 5.09 & $19.67 * *$ & $39.94 * *$ & $12.31 * *$ & 2.05154 \\
\hline Panicle exertion $(\mathrm{cm})$ & 0.49 & $4.85 * *$ & $15.43 * *$ & $2.82 * *$ & 0.87474 \\
\hline $\begin{array}{l}\text { Number of effective } \\
\text { tillers }\end{array}$ & 20.47 & $181.14 * *$ & $461.20 * *$ & $111.23 * *$ & 42.7898 \\
\hline $\begin{array}{l}\text { Number of seed per } \\
\text { panicle }\end{array}$ & 24.62 & $6263.00 * *$ & $12478.29 * *$ & $3897.31 \mathrm{~ns}$ & 562.205 \\
\hline 1000 grain weight $(\mathrm{g})$ & 0.06 & $26.11 * *$ & $60.71 * *$ & $14.44 * *$ & 2.68021 \\
\hline 1st iron score (ses) & 2.13 & $4.84 * *$ & $15.20 * *$ & $2.21 \mathrm{~ns}$ & 1.75461 \\
\hline $2^{\text {nd }}$ iron score (ses) & 2.59 & $10.30 * *$ & $20.05 * *$ & $1.73 * *$ & 1.88636 \\
\hline
\end{tabular}

** = Significant at 0.01 probability level $; \mathrm{df}=$ Degree of freedom

NB: Leaf bronzing score ranged from 1.0 to 9.0 in response to pulse stress according to IRRI (2001), Standard evaluation system (SES), 1.0 is considered highly resistance, 3.0 resistance, 5.0 moderately susceptible, 7.0 susceptible and 9.0 highly susceptible. 
COMBINING ABILITY STUDIES ON YIELD AND YIELD COMPONENTS IN RICE GENOTYPES...

Table 5. Estimate of General combining ability and specific combining ability effects for grain yield and other agronomic traits of rice under irontoxicity condition at Edozhigi in 2018

\begin{tabular}{|c|c|c|c|c|c|c|c|c|c|c|c|c|}
\hline Genotype & $\begin{array}{l}\text { Grain } \\
\text { yield }\end{array}$ & $\begin{array}{c}\text { Days to } \\
50 \% \\
\text { flowering }\end{array}$ & $\begin{array}{l}\text { Number } \\
\text { of tillers }\end{array}$ & $\begin{array}{l}\text { Number } \\
\text { of leaves }\end{array}$ & $\begin{array}{l}\text { Plant } \\
\text { height }\end{array}$ & $\begin{array}{l}\text { Panicle } \\
\text { length }\end{array}$ & $\begin{array}{c}\text { Number } \\
\text { of seeds } \\
\text { per } \\
\text { panicle }\end{array}$ & $\begin{array}{c}\text { Panicle } \\
\text { exertion }\end{array}$ & $\begin{array}{c}\text { No. of } \\
\text { effective } \\
\text { tillers }\end{array}$ & $\begin{array}{c}1000 \\
\text { grain } \\
\text { weight }\end{array}$ & $\begin{array}{l}1^{\text {st }} \text { iron } \\
\text { score }\end{array}$ & $\begin{array}{c}2^{\text {nd }} \text { iron } \\
\text { score }\end{array}$ \\
\hline \multicolumn{13}{|l|}{ Parent } \\
\hline Faro 44 & $-24.41 * *$ & $2.46^{*}$ & $-4.56^{* * *}$ & 0.11 & $-16.13 * *$ & $-1.63 * *$ & $-31.14 * *$ & $0.78 * *$ & $-5.60 * *$ & -0.32 & $1.02 * *$ & $1.65^{* *}$ \\
\hline Faro 52 & $19.93 * *$ & 1.84 & 0.08 & -0.15 & $-4.58^{* *}$ & $0.94 * *$ & 3.91 & -0.22 & -0.12 & $-2.09 * *$ & -0.1 & -0.19 \\
\hline Faro 60 & $-26.93 * *$ & $-6.70^{* * *}$ & $-2.81 * *$ & 0.06 & $-10.52 * *$ & $-1.22 * *$ & $-18.77 * *$ & $1.03 * *$ & $-2.81 * *$ & $-0.69^{* *}$ & $0.44^{*}$ & $0.73^{* *}$ \\
\hline Faro 57 & $12.64^{* * *}$ & $3.42 * *$ & 0.74 & $0.24 * *$ & $-4.23 *$ & $0.65 * *$ & $28.36^{* *}$ & -0.14 & 0.84 & -0.19 & 0.31 & $0.81 * *$ \\
\hline Faro 61 & $-27.38 * *$ & $-2.12 *$ & $-3.49 * *$ & $0.76^{* *}$ & $-14.38 * *$ & $-1.37 * *$ & $-7.17 *$ & $0.45^{* *}$ & $-4.38 * *$ & $-1.18^{* *}$ & $0.60 * *$ & $0.81^{* *}$ \\
\hline Suakoko 8 & $8.67 * *$ & $3.42 * *$ & 1.03 & $-0.90 * *$ & $8.90 * *$ & $1.43 * *$ & -1.82 & -0.22 & 1.5 & $2.23 * *$ & $-0.73^{* *}$ & $-1.19^{* *}$ \\
\hline CK-21 & $19.25 * *$ & $3.26^{* * *}$ & $4.64^{* *}$ & $-0.46^{* *}$ & $22.51 * *$ & $1.02 * *$ & $30.82 * *$ & $-0.97 * *$ & $5.04 * *$ & 0.22 & $1.23 * *$ & $-1.52^{* *}$ \\
\hline CK-43 & $18.23^{* *}$ & $-5.58^{* *}$ & $4.37 * *$ & $0.34 * *$ & $18.43^{* *}$ & 0.18 & -4.2 & $-0.71875^{* *}$ & $5.53 * *$ & $2.03 * *$ & -0.31 & $-1.10^{* *}$ \\
\hline $\mathrm{SE} \pm$ & 1.23 & 0.98 & 0.58 & 0.09 & 1.72 & 0.20 & 3.24 & 0.13 & 0.85 & 0.21 & 0.18 & 0.19 \\
\hline Faro 44 x Faro 52 & $-24.07 * *$ & -1.63 & -1.26 & 0.1 & -8.2 & $-2.01 * *$ & -10.89 & 0.47 & -1.68 & $1.38^{*}$ & $1.02 *$ & $1.27^{*}$ \\
\hline Faro 44 x Faro 60 & $14.16^{* *}$ & $-11.76^{* *}$ & 0.7 & -0.31 & -4.79 & 1.01 & $-17.75^{*}$ & $1.22 * *$ & -3.32 & -0.75 & $1.15^{*}$ & 0.35 \\
\hline Faro 44 x Faro 57 & -3.77 & $8.79^{* *}$ & 3.82 & 0.11 & 1.32 & 0.01 & $45.39 * *$ & $-1.61 * *$ & 3.56 & 0.78 & -0.73 & -0.4 \\
\hline Faro 44 x Faro 61 & $13.77 * *$ & 3.66 & -2.75 & -0.32 & 0.6 & $-1.58 * *$ & -14.48 & $1.14^{* *}$ & -2.36 & 0.01 & -0.35 & 0.27 \\
\hline Faro 44 x Suakoko 8 & $-8.51^{* *}$ & $9.45^{* *}$ & -1.8 & 0.05 & $13.19^{* *}$ & 0.49 & 2.97 & -0.2 & -0.7 & 0.03 & -0.35 & $-1.06^{*}$ \\
\hline Faro 44 x CK- 21 & $-6.75^{*}$ & -3.71 & 2.65 & $0.61^{*}$ & 2.05 & 0.84 & $19.20^{*}$ & $-0.78^{*}$ & $5.29 *$ & -0.83 & 0.15 & 0.6 \\
\hline Faro 44 x CK- 43 & $-25.17 * *$ & $-16.96^{* *}$ & 4.94 & -0.83 & 2.18 & 1.18 & 22.33 & -0.5 & 5.87 & 0.35 & -0.67 & 0.08 \\
\hline Faro $52 \times$ Faro 60 & $-10.51^{* *}$ & 0.2 & 1.73 & -0.25 & $28.79^{* *}$ & $2.10 * *$ & $18.67^{*}$ & $-1.11^{* *}$ & 3.46 & -0.94 & $-1.73 * *$ & $-1.81 * *$ \\
\hline Faro $52 \times$ Faro 57 & -0.08 & $-7.92 * *$ & -7.65 & 0.03 & $-16.03^{* *}$ & $-2.13 * *$ & $-72.99 * *$ & $1.39 * *$ & $-9.63^{* *}$ & $1.20^{*}$ & 0.73 & $1.44 * *$ \\
\hline
\end{tabular}


Maiwa'azi Abu BARDE \& al.

\begin{tabular}{|c|c|c|c|c|c|c|c|c|c|c|c|c|}
\hline \multicolumn{13}{|c|}{ Table 5. (cont.) } \\
\hline Genotype & Grain yield & $\begin{array}{c}\text { Days to } \\
50 \% \\
\text { flowering } \\
\end{array}$ & $\begin{array}{l}\text { Number } \\
\text { of tillers }\end{array}$ & $\begin{array}{l}\text { Number } \\
\text { of leaves }\end{array}$ & $\begin{array}{c}\text { Plant } \\
\text { height }\end{array}$ & $\begin{array}{l}\text { Panicle } \\
\text { length }\end{array}$ & $\begin{array}{l}\text { Number } \\
\text { of seeds } \\
\text { per pan }\end{array}$ & $\begin{array}{c}\text { Panicle } \\
\text { exersion }\end{array}$ & $\begin{array}{c}\text { No. of } \\
\text { effective } \\
\text { tillers }\end{array}$ & $\begin{array}{c}1000 \\
\text { grain } \\
\text { weight }\end{array}$ & $\begin{array}{c}1^{\text {st }} \text { iron } \\
\text { score }\end{array}$ & $\begin{array}{c}2^{\text {nd }} \text { iron } \\
\text { score }\end{array}$ \\
\hline Faro 52 x Faro 61 & -2.74 & -5.05 & 2.68 & 0.25 & 5.52 & $2.12 * *$ & $85.67 * *$ & $-1.20 * *$ & $5.62 *$ & $3.61 * *$ & -0.56 & 0.1 \\
\hline Faro 52 x Suakoko 8 & 2.55 & $9.41^{* *}$ & 9.83 & 0.11 & 3.11 & 0.59 & $53.25 * *$ & -0.53 & $11.15^{* *}$ & $-2.57 * *$ & 0.1 & -0.56 \\
\hline Faro 52 x CK- 21 & $9.24 * *$ & -11.4 & -0.66 & 0.07 & -8.83 & $-1.33^{*}$ & $-53.12 * *$ & 0.22 & $-5.39 *$ & $-2.56^{* *}$ & $-0.73 *$ & $-0.9^{*}$ \\
\hline Faro 52 x CK- 43 & $-19.03 * *$ & -6.92 & -9.95 & $-1.29 * *$ & 0.59 & 0.22 & 3.31 & $1.83 * *$ & $-10.91 *$ & $-4.22 * *$ & $2.21^{*}$ & $2.25^{*}$ \\
\hline Faro 60 x Faro 57 & $-8.92 * *$ & $-14.05^{* *}$ & 3.27 & $0.56^{*}$ & 2.84 & -0.54 & 1.22 & $0.80 *$ & 3.7 & $1.83 * *$ & -0.15 & $1.19^{*}$ \\
\hline Faro 60 x Faro 61 & $18.10 * *$ & $17.49 * *$ & -3.63 & 0.17 & -3.61 & $-3.59 * *$ & $-35.19 * *$ & $0.89^{*}$ & $-5.81 *$ & -0.22 & $1.56^{* *}$ & $1.19^{*}$ \\
\hline Faro $60 \mathrm{x}$ Suakoko 8 & $-7.99 *$ & $-14.05^{* *}$ & 3.45 & -0.37 & 5.52 & $3.34 * *$ & $23.66 * *$ & -0.45 & $7.91 * *$ & -0.96 & $-1.10^{*}$ & -0.15 \\
\hline Faro $60 \times$ CK-21 & $-12.26^{* *}$ & $16.45 * *$ & -0.37 & -0.01 & $-17.49^{* *}$ & 0.03 & 14.42 & $-1.03 * *$ & 0.84 & $2.45^{* *}$ & 0.06 & $-1.15^{*}$ \\
\hline Faro $60 \times$ x CK- 43 & $-35.43 *$ & $-13.13 * *$ & -4.38 & 0.72 & $34.98 * *$ & $6.20 * *$ & $52.83^{* *}$ & $-2.25 * *$ & 4.53 & $-2.13 *$ & -0.58 & $-2.17 *$ \\
\hline Faro 57 x Faro 61 & $-12.84 * *$ & $10.37 * *$ & 1.15 & $0.72 * *$ & -1.16 & 0.88 & 8.28 & -0.61 & 2.6 & $-2.05 * *$ & -0.31 & $-1.56^{* *}$ \\
\hline Faro 57 x Suakoko 8 & $-35.09 * *$ & -1.51 & -3.63 & -0.08 & -4.51 & $-1.72 * *$ & -11.07 & 0.72 & $-4.74 *$ & $-1.43^{*}$ & 0.35 & -0.9 \\
\hline Faro 57 x CK- 21 & -2.80 & -1.34 & 2.95 & -0.19 & $17.89^{* *}$ & -0.77 & -4.37 & 0.14 & 1.58 & -0.35 & 0.19 & 0.77 \\
\hline Faro 57 x CK- 43 & $-36.33 * *$ & $-11.33^{*}$ & -16.03 & 0.63 & $32.41 * *$ & -1.6 & $-37.04 *$ & 0.58 & $-17.69 * *$ & $-2.49^{*}$ & 1.29 & 1.25 \\
\hline Faro 61 x Suakoko 8 & $-9.28 * *$ & $-6.63^{*}$ & -0.13 & 0.13 & $-20.49 * *$ & -1.18 & $-25.74 * *$ & 0.8 & -3.32 & $-2.44 * *$ & 0.73 & $1.10^{*}$ \\
\hline Faro 61 x CK- 21 & $-23.72 * *$ & 1.87 & -2.86 & $-0.51^{*}$ & $18.64 * *$ & $2.31 * *$ & 13.16 & -0.45 & $4.47^{*}$ & $1.64 * *$ & -0.77 & -0.56 \\
\hline Faro 61 x CK- 43 & $-32.97 * *$ & 2.46 & 1.85 & $0.89 *$ & 6.26 & 0.85 & $92.43 * *$ & -0.83 & 2.09 & -1.88 & -0.42 & -1.42 \\
\hline Suakoko 8 x CK-21 & $24.00 * *$ & $-12.01 * *$ & -9.27 & 0.08 & -6.91 & -0.63 & $-28.79 * *$ & 0.22 & $-10.54 *$ & -0.47 & 0.56 & 0.77 \\
\hline Suakoko 8 x CK- 43 & 2.78 & $21.00 * *$ & 3.39 & $-1.91 * *$ & 2.27 & 0.52 & $-48.75 * *$ & 0.5 & 0.5 & 0.99 & 0.92 & -0.08 \\
\hline CK- 21 x CK- 43 & $-26.88^{* *}$ & $-15.50 * *$ & 20.34 & 0.67 & 2.08 & $-2.57^{*}$ & 16.22 & -0.25 & $18.31^{* *}$ & $-4.82 * *$ & -1.58 & -0.42 \\
\hline $\mathrm{SE} \pm$ & 3.28 & 2.63 & 2.92 & 0.24 & 4.59 & 0.54 & 8.67 & 0.35 & 2.28 & 0.57 & 0.48 & 0.52 \\
\hline
\end{tabular}


The result showed highly significant positive GCA effects for CK-21 and CK-43 (4.64 and 4.37), respectively, and highly significant negative GCA effects were also observed for FARO 44 (-4.56), FARO 60 (-2.81) and FARO 61 (-3.49). Highly significant positive GCA effects were observed for number of leaves for FARO 57 (0.24), FARO 61 (0.076) and CK-43 (0.34) and highly significant negative GCA effects were recorded for Suakoko 8 ($0.90)$ and CK-21 (-0.34). A highly significant positive GCA effects were observed for plant height for Suakoko 8 (8.90), (CK-21 (22.51) and CK-43 (18.43) while a significant negative GCA effects were observed for FARO 44 (-16.13), FARO 60 (-10.52), FARO 52 (-4.85) and FARO 61 (-14.38). Highly significant positive GCA effects were observed for panicle length for FARO 52 (0.94), FARO 57 (0.65) and FARO 61 (-1.37) showed highly significant negative GCA effects. Highly significant positive GCA effects were for number of seeds per panicle for FARO 57 (28.36) and CK-21 (30.82), while FARO 44 (-31.14) and FARO 60 (18.77) showed highly significant GCA negative effects. The significant positive GCA effects were observed for panicle exertion $61(0.45)$ and FARO 60(1.03) while CK-21 (-0.97) and CK- 43 (-0.72) recorded highly significant negative GCA effects. On number of effective tillers, CK-21 (5.04) and CK-43 (5.53) recorded highly significant positive GCA effects while FARO 44 (-5.60), FARO 60 (-2.81) and FARO 61 (-4.38) showed highly significant negative GCA effects. On one thousand (1000) grain weight Suakoko 8 (2.23) and CK-43 (2.03) showed highly significant positive GCA effects whereas highly significant negative GCA effects were observed for FARO 52 (-2.09), FARO 60 (-0.69 and FARO 61 (-1.18). First iron toxicity score, showed highly significant positive GCA effects for FARO 44 (1.02) and FARO 61 (0.60) while highly significant negative GCA effects was observed for Suakoko $8(-0.73)$ and CK-21 (-1.23). The second iron toxicity score showed highly significantly positive GCA effects for FARO 44 (1.65), FARO 60 (0.73), FARO 57 (0.81) and FARO 61 (0.81) while Suakoko 8, CK-21, and CK- 43 recorded highly significant negative GCA effects (-1.19), (-1.52), and (-1.10), respectively.

Estimate of specific combining ability (SCA) effects for grain yield and other Agronomic Traits of Rice under Iron Toxicity Hotspot at Edozhigi.

A highly significant $(\mathrm{P}<0.01)$ positive SCA effects for grain yield were observed for FARO 52 x CK-21 (9.24) and also showed high significant negative SCA effects for first and second iron toxicity scores (-0.73) and (-0.9), respectively, (Table 4). Highly significant $(\mathrm{p}<0.01)$ positive SCA effects were observed for days to $50 \%$ flowering in Suakoko 8 x CK$43(21.00)$ and highly significant $(\mathrm{p}<0.01)$ negative SCA effects were observed for FARO 60 x FARO 57 (-14.05).

Highly significant positive SCA effects were observed for number of leaves for FARO 57 x FARO $61(0.72)$ and highly significant $(\mathrm{p}<0.01)$ negative SCA effects were observed for Suakoko 8 x CK- $43(-1.91)$. High significant $(\mathrm{P}<0.05)$ positive SCA effects for number of leaves for FARO 44 x CK-21 (0.61) while FARO 52 x CK-43 (-1.29) showed highly significant negative SCA effects for number of leaves. Highly significant positive SCA effects for plant height were observed for FARO 57 x CK-43 (32.41) and highly significant negative SCA effects for plant height were observed for FARO 61 x Suakoko 8 $(-20.49)$.

Highly significant positive SCA effects were observed for panicle length for FARO 52 x FARO 60 (2.10) while highly significant negative SCA effects were observed for panicle length for FARO $44 \mathrm{x}$ FARO 61 (-1.58). Highly significant positive SCA effects were observed for number of seeds per panicle for FARO 61 x CK-43 (92.43) and highly 
Maiwa'azi Abu BARDE \& al.

significant negative SCA effects were observed for number of seeds per panicle for FARO 52 x FARO 57 (-72.99). Highly significant positive SCA effects were observed for panicle exertion for FARO 44 x FARO 60 (1.22), while highly significant, but negative SCA effects were expressed in FARO 44 x FARO 57 (-1.61). High significant positive SCA effects were observed for number of effective tillers for FARO 44 x CK-21 (5.29) and significant negative effects was observed in FARO 52 x CK- 21 (-5.39). While highly significant positive SCA effects were recorded for one thousand (1000) grain weight for FARO 52 x FARO 61 (3.61) and highly significant negative SCA effects were observed for FARO 52 x Suakoko 8 (-2.57). First iron toxicity score showed highly significant positive SCA effects in FARO $60 \mathrm{x}$ FARO 61 (1.56) and highly significant negative SCA effects were observed for FARO 52 x 60 (1.73). Second iron toxicity score showed highly significant positive SCA effects in FARO 52 x FARO 57 (1.44) and while highly significant negative SCA effects were observed in FARO 52 x FARO 60 (-1.81).

\section{Variance component of GCA and SCA on iron toxicity and agronomic traits of rice $\mathrm{F} 1$ genotypes}

The GCA variances were generally higher than the SCA variances for all the traits studied except for days to 50\% flowering (9207.92), number of tillers (2357.88), panicle length (344.74) and number of seeds per panicle (109124.58), (Table 6). The highest GCA were observed in grain yield (91322.48) followed by number of seeds per panicle (87348.01) and plant height (42541.75) whereas the lowest were associated with number of leaves (49.75), panicle exertion (94.45) and $1^{\text {st }}$ iron score (106.07). The number of seeds per panicle (109124.58) revealed the highest SCA followed by grain yield (31149.61) and plant height (16080.11) while the lowest were linked with number of leaves (26.26), panicle exertion (69.10) and first iron score (61.87). The GCA/SCA ratios ranged from 0.39 for days to $50 \%$ flowering to 2.93 for grain yield. The highest ratio was reported for grain yield (2.93) followed by $2^{\text {nd }}$ iron score (2.90) and plant height (2.65) while the lowest were seen in days to $50 \%$ flowering $(0.39)$ followed by number of seeds per panicle $(0.80)$, number of tillers (0.97) and panicle length (0.81). The following traits: days to $50 \%$ flowering, number tillers, panicle length and number of seeds per panicle recorded GCA/SCA ratios less than one (1) less than unity.

Table 6. Variance component of GCA and SCA on iron toxicity agronomic traits of rice $\mathrm{F}_{1} \mathrm{~S}$ at Edozhigi in 2018

\begin{tabular}{lccc}
\hline Source of variation & & & $\sigma_{G C A}^{2}$ \\
& $\sigma_{G C A}^{2}$ & 31149.61 & $\sigma_{S C A}^{2}$ \\
\hline Grain yield (kg/ha) & 91322.48 & 9207.92 & 2.93 \\
\hline Days to flowering & 3611.95 & 2357.88 & 0.39 \\
\hline Number of tillers & 2285.46 & 26.26 & 0.97 \\
\hline Number of leaves & 49.75 & 16080.11 & 1.9 \\
\hline Plant height (cm) & 42541.75 & 344.74 & 2.65 \\
\hline Panicle length $(\mathrm{cm})$ & 279.56 & 109124.58 & 0.81 \\
\hline Number of seeds per panicle & 87348.01 & 69.1 & 0.8 \\
\hline Panicle exertion $(\mathrm{cm})$ & 94.45 & 1.37
\end{tabular}


COMBINING ABILITY STUDIES ON YIELD AND YIELD COMPONENTS IN RICE GENOTYPES...

\begin{tabular}{lccc}
\hline Number of effective tillers & 3229.08 & 3114.52 & 1.04 \\
1000 grain weight $(\mathrm{g})$ & 425 & 404.34 & 1.05 \\
$1^{\text {st }}$ iron score (ses) & 106.07 & 61.87 & 1.71 \\
$2^{\text {nd }}$ iron score (ses) & 264.76 & 91.32 & 2.9 \\
\hline
\end{tabular}

NB: Leaf bronzing score ranged from 1.0 to 9.0 in response to pulse stress according to IRRI (2001), Standard evaluation system (SES), 1.0 is considered highly resistance, 3.0 resistance, 5.0 moderately susceptible, 7.0 susceptible and 9.0 highly susceptible.

\section{Discussion}

The analysis variance for gene action showed highly significant difference among the genotypes for all traits measured with both additive genes and non additive genes playing important roles in most of the traits. However, the SCA revealed the existence of highly significant differences for most of the traits except for number of seeds per panicle and first iron toxicity score for which the difference was not significant. The relatively greater importance of GCA than SCA implies that breeding progress could be effective using recurrent selection in improving yield and other traits in iron toxicity condition. This present study is in conformity with the results reported by ISMAILA (2012).

Combining ability refers to the ability of a parent to transmit desirable performance to its hybrid progenies or crosses. PAINKRA (2014) pointed out that combining ability of parents gives important information of the choice of parent in terms of expected performance of their progenies. The significance of GCA and SCA mean squares suggested the importance of both additive and non-additive variances for all the characters studied. The highly significant positive GCA effects observed among, SUAKOKO 8, CK-21, FARO 52, and CK43 for grain yield and also highly significant negative GCA effects of first and second iron scores indicated that these parents are tolerant to iron toxicity and may be preferred for hybridization and selection programmes. The SCA effects revealed that for hybrid rice development, cross FARO 52 x CK-21 with highly significant positive SCA effects for grain yield and with high significant negative SCA effects of first and second iron toxicity scores could be better choice for most of the traits including yield under iron toxicity condition. This showed combining ability and gene effects revealing contribution of both additive and non additive gene effects playing important roles for all traits studied. This is in conformity with the results reported by PAINKRA (2014). Positive GCA effects are desirable for grain yield and number of effective tillers, but negative GCA effects are desirable for rice crop plant height because of lodging and days to $50 \%$ flowering because of earliness. In the present study, parents FARO 52 and FARO 57 were found to be good general combiners in the right direction for grain yield per plant, plant height and number of effective tillers. Similar findings were recorded by GNANASEKARAN \& al. (2006), SHARMA (2006), ISMAILA \& ECHEKWU (2015) whose research work reported rice genotypes with good GCA effects for plant height and number of tillers. The parent materials are potential varieties for future breeding programmes aimed at developing new hybrids tolerant to iron toxicity.

SCA effect is the index that determines the usefulness of a particular cross combination in the exploitation of heterosis. Shorter culm reduces the respiratory loss. On the other hand, tall stature facilitates light penetration. Thus an optimum plant height is however, desirable. Short statured plant height is a desirable trait in rice crop to avoid greater yield loss due to lodging. This is in line with CHANDRASEKARAN \& al. (2007). Six 
Maiwa'azi Abu BARDE \& al.

hybrids FARO 44 x SUAKOKO 8, FARO 52 x FARO60, FARO 60 x CK-43, FARO 57 x CK-21, FARO 57 x CK-43 and FARO 61 x CK-21 expressed positive SCA effects reflecting an increase in plant stature. FARO 52 x FARO 57, FARO $60 \times$ CK-21 and FARO $61 \times$ SUAKOKO 8 showed negative SCA fell in the category of average effects. The cross FARO 52 x FARO 57 exhibited the best showing negative SCA effects for plant height indicating that improvement in plant height in terms of intermediate or short stature can be achieved by exploitation of hybrid vigor in this cross combination.

Number of effective tillers per plant and increased panicle length are also desirable traits for increased grain yield per plant in rice. The cross combinations FARO $44 \times$ FARO 60, FARO 44 x FARO 57, FARO 44 x CK-21, FARO 44 x CK-43, FARO 52 x FARO 60, FARO 52 x FARO 61, FARO 52 x SUAKOKO 8, FARO 60 x FARO 57, FARO 61 x CK43, SUAKOKO 8 x CK-43 and CK-21 x CK-43 had positive SCA effects for number of effective tillers per plant. These results are in conformity with the reports of MEHLA \& al. (2000), SHARMA \& MANI (2005) and SHARMA (2006) who reported similar SCA estimates of number of tillers per plant. Grain yield is the ultimate objective of rice breeding programme. The cross combinations; FARO 44 x FARO 60, FARO 44 x FARO 61, FARO 52 x CK-21, FARO 60 x FARO 61 and SUAKOKO 8 x CK-21 had positive SCA effects for grain yield per plot indicating relative importance of non-additive gene effects for these traits. ISMAILA (2012) reported that non-additive gene effects were predominant for grain yield and its components. In the present study, it was observed that cross combinations which expressed high SCA effects for grain yield, invariably exhibited positive SCA effects for one or more yield related traits also. These results are in line with ISMAILA \& ECHEKWU (2015), who reported good specific cross combinations in rice. None of the cross combinations were found to be good specific cross combinations for all the characters studied. Generally, in most of the cross combinations at least one general combiner was involved for all the traits under study along with grain yield. It also indicated both additive and none-additive types of gene action. While selecting the best specific combination for yield, it would be important to give due considerations to yield related traits. Leaf bronzing score is often recorded to screen plants for tolerance to ferrous iron toxicity [DEVI \& al. 2016]. In the study, leaf symptom scoring was performed to study the rice genotypes' response to excess iron. The rice genotypes showed varying degrees of leaf bronzing in response to excess iron. Leaf bronzing score ranged from 1.0 to 9.0 in response to pulse stress according to IRRI (2001), Standard evaluation system (SES), 1.0 is considered highly resistance, 3.0 resistance, 5.0 moderately susceptible, 7.0 susceptible and 9.0 highly susceptible. Parents Suakoko 8, Ck-21 and Ck-43 with high significant positive GCA effects and with high significant negative GCA effects of iron scores can be utilized for hybridization programme for selection of superior combination in segregating progenies in iron toxicity condition as explained by MULLER \& al. (2015). This study conforms to the results reported by DEVI \& al. (2016), that such varieties are capable of oxidizing large amount of iron translocated to the shoots.

Gene action refers to the behavior or mode of expression of gene in a genetic population. The ratio of GCA to SCA (additive / non additive genes) ranged from 0.39 (days to $50 \%$ flowering) to 2.93 (grain yield). Among the twelve traits, four: days to $50 \%$ flowering, number of tillers, panicle length and number of seeds per panicle showed less than unity (lower than 1) and eight recorded more than unity (greater than 1). Lower than unity indicated higher importance of non additive genes in the expression of the traits or non additive component had a more significant role in the inheritance of days to $50 \%$ to flowering, number 
of tillers, panicle length and number of seeds per panicle. Furthermore, GCA/SCA ratio in the hybrids lower than one (1) indicated that the non additive component of genetic variance made a larger contribution to the total genetic variance for grain yield than the additive one as reported by DRAGAN \& al. (2000). Traits showing more than unity indicate preponderance of additive gene action in inheritance of these traits. Similar results were reported by PAINKRA (2014).

\section{Conclusions}

Presence of substantial additive gene effects suggests that reciprocal recurrent selection would be effective in improving populations and developing superior cultivar for iron toxicity soil. Based on mean performance of populations, their GCA effects, recurrent selection that exploit both GCA and SCA effects, would include Faro 57, Faro 52, CK-21, CK-43 and suakoko 8 for developing superior cultivars under iron toxicity conditions. Additive gene and non-additive gene actions were observed for the control of all measured traits including iron toxicity in the study, indicating the possibility of developing desirable genotypes that can be advanced for selection and production under iron toxicity, or used in rice breeding programmes.

Recommendations. The following recommendations are highlighted from the present study: the iron toxicity tolerant rice genotypes (FARO 52, SUAKOKO 8, CK-21 and CK-43) were identified as good combiners in the study which could be useful to rice breeders interested in breeding for iron toxicity tolerance and synthetic cultivars for iron toxicity prone regions in Nigeria.

The $\mathrm{F}_{1}$ genotype identified in this study including FARO 52 x CK-21 with highly significant positive SCA effects for grain yield (9.24) and with high significant negative effects of first and second iron toxicity scores $(-0.73)$ and $(-0.90)$, respectively, should be tested extensively in more hot spot regions prone to iron toxicity for adoption and production to alleviate food security problems in Nigeria.

\section{Notes on contributors}

Maiwa'azi Abu BARDE is a plant breeder/seeds specialist, currently working on iron toxicity in rice. Works at National Agricultural Seeds Council, Jos, Nigeria.

Mohammed Sagir MOHAMMED, PhD in Plant Breeding. Postgraduate Coordinator and a Lecturer at Plant Science Department, Ahmadu Bello University Zaria, Nigeria.

Muhyideen OYEKUNLE, PhD in Plant Breeding/Maize Breeder, Institute for Agriculture Research, Plant Science Department, Ahmadu Bello University Zaria, Nigeria.

Inuwa Shehu USMAN, Professor of Plant Physiology, Head of Biofactory, Plant Science Department, Ahmadu Bello University Zaria, Nigeria.

Aondover SHAAHU is a PhD student/Researcher, currently working on soybean breeding and evaluation of advanced lines at National Cereals Research Institute, Badeggi, Nigeria.

\section{References}

CHANDRASEKARAN B., ANNADURAI K. \& KARVIMANI R. 2007. A Textbook of Rice Science. Scientific Publishers. Jodhpur (Raj), India: 46 pp.

CHERIF M., AUDEBERT A., FOFANA M. \& ZOUZOU M. 2009. Evaluation of iron toxicity on lowland irrigated rice in West Africa. Tropicultura. 27(2): 88-92. 
DEVI A. G., RANGAPPA K., YADAV G. S., DEVI H. L. \& NGACHAN S. V. 2016. Effects of acute iron toxicity on key antioxidative enzymes in contrasting rice (Oryza sativa L.) cultivars of North-East India. International Journal of Bio-resource and Stress Management. 7(3): 388-392. https://doi.org/10.23910/IJBSM/2016.7.3.1572

DRAGAN S., SINISA J. \& IGOR M. 2000. General (GCA) and Specific (SCA) combining ability in Sunflower. Institute of Field and Vegetable Crops, Maksima Gorkog 30, 21000 Novi Sad, Yugoslavia.

FUKUDA A., SHIRATSUCHI H., FUKUSHIMA A., YAMAGUCHI H., MOCHIDA H., TERAO T. \& OGIWARA H. 2012. Detection of chromosomal regions affecting iron concentration in rice shoots subjected to excess ferrous iron using chromosomal segment substitution lines between Japonica and Indica. Plant Production Science. 15(3): 183-191. https://doi.org/10.1626/pps.15.183

GNANASEKARAN M., VIVEKANANDAN P. \& MUTHURAMU S. 2006. Combining ability and heterosis for yield and grain quality in two line rice (Oryza sativa L.) hybrids. Indian Journal of Genetics. 66(1): 6-9.

GUIMARAES E. P. 2009. Rice breeding. In: CARENA M. J. (ed.). Handbook of plant breeding. Vol 3: Cereals, Springer, Berlin/Heidelberg, Alemania.

IRRI. 2001. Rice Statistics: Standard Evaluation System (SES). Accessed online http//oryzacom/Africa/nigerial/index.hshtmlon $27^{\text {th }} 2007$.

ISMAILA A. \& ECHEKWU C. A. 2015. Genetics of some agronomic and yield traits in rice (Oryza sativa L.). International Journal of Sciences and Research. 4(10): 1321-1326.

ISMAILA A. 2012. Genetics of some agronomic and yield traits in rice (Oryza sativa L.). M. Sc. Thesis Department of Plant Science, Ahmadu Bello University, Zaria, Nigeria.

MANDAL A. B., BASU A. K., ROY B., SHEEJA T. E. \& ROY T. 2004. Genetic management for increased tolerance to aluminium and iron toxicities. Indian Journal of Biotechnology. 3: 359-368.

MEHLA I. S., SINGH A., PANWAR D. V. S. \& SINGH A. 2000. Combining ability studies for yield and its components in rice hybrids. Agricultural Science Digest. 20(3): 146-149.

MOHANAN K. V. 2010. Essentials of Plant Breeding. Published by Asoke K. Ghosh, PHI Learning Private Limited, M-97, Connaught Circus, New Delhi-110001 and Printed by Mudrak, 30-A, Patparganj, Delhi 110091: 76 pp.

MULLER C., KUKI K. N., PINHEIRO D. T., DE SOUZA L. R., SIQUEIRA SILVA A. I., LOUREIRO M. E., OLIVA M. A. \& ALMEIDA A. M. 2015. Differential Physiological responses in rice upon exposure to excess distinct iron forms. Plant Soil. 391: 123 -138. https://doi.org/10.1007/s11104-015-2405-9

NARTEH L. T. \& SAHRAWAT K. L. 1999. Influence of flooding on electrochemical and chemical properties of West African soils. Geoderma. 87: 178-207.

NCRI. 2012. Manual for training the Trainers workshop on rice Production, Processing and Marketing, Yenagoa Bayelsa, 3-7 September, 2012: 84 pp.

OGAH E. O. 2013. Evaluating the impact of new rice for Africa (Nerica) in management of rice stem borer. Science International. 1: 160-166. https://doi.org/10.17311/sciintl.2013.160.166

PAINKRA P. 2014. Identification of desirable parents and cross combinations in soybeans (Glycine max L. Merrill.) for C. G. plain. Thesis submitted to the Indira Gandhi KrishiVishwavidyalaya, Raipur (C. G.): 42-53.

SALGOTRA R. K., GUPTA B. B. \& SINGH S. 2009. Evaluation of various floral traits in some rice CMS lines that influence seed setting under subtropical conditions. SABRAO Journal of Breeding and Genetics. 41(2): 115-122.

SAS. 2002. Statistical Analysis System (Version 9) by SAS Institute Inc., Cary, NC, USA.

SHARMA R. K. \& MANI S. C. 2005. Combining ability and gene action for quality characters in Basmati rice (Oryza sativa L.). Indian Journal of Genetics. 65(2): 123-124.

SHARMA R. K. 2006. Studies on gene action and combining ability for yield and its component traits in rice (Oryza sativa L.). Indian Journal of Genetics. 66(3): 227-228.

\section{How to cite this article:}

BARDE M. A., MOHAMMED M. S., OYEKUNLE M., USMAN I. S. \& SHAAHU A. 2021. Combining ability studies on yield and yield components in rice genotypes (Oryza sativa L.). J. Plant Develop. 28: 109-121. https://doi.org/10.47743/jpd.2021.28.1.854 